IZA DP No. 694

What Determines the Reservation Wages of Unemployed Workers?

New Evidence from German Micro Data

Eswar E. Prasad

J anuary 2003 


\title{
What Determines the Reservation Wages of Unemployed Workers? New Evidence from German Micro Data
}

\author{
Eswar S. Prasad \\ International Monetary Fund and IZA Bonn
}

Discussion Paper No. 694

January 2003

\author{
IZA \\ P.O. Box 7240 \\ D-53072 Bonn \\ Germany \\ Tel.: +49-228-3894-0 \\ Fax: +49-228-3894-210 \\ Email: iza@iza.org
}

This Discussion Paper is issued within the framework of IZA's research area Welfare State and Labor Market. Any opinions expressed here are those of the author(s) and not those of the institute. Research disseminated by IZA may include views on policy, but the institute itself takes no institutional policy positions.

The Institute for the Study of Labor (IZA) in Bonn is a local and virtual international research center and a place of communication between science, politics and business. IZA is an independent, nonprofit limited liability company (Gesellschaft mit beschränkter Haftung) supported by the Deutsche Post AG. The center is associated with the University of Bonn and offers a stimulating research environment through its research networks, research support, and visitors and doctoral programs. IZA engages in (i) original and internationally competitive research in all fields of labor economics, (ii) development of policy concepts, and (iii) dissemination of research results and concepts to the interested public. The current research program deals with (1) mobility and flexibility of labor, (2) internationalization of labor markets, (3) welfare state and labor market, (4) labor markets in transition countries, (5) the future of labor, (6) evaluation of labor market policies and projects and (7) general labor economics.

IZA Discussion Papers often represent preliminary work and are circulated to encourage discussion. Citation of such a paper should account for its provisional character. A revised version may be available on the IZA website (www.iza.org) or directly from the author. 


\title{
ABSTRACT \\ What Determines the Reservation Wages of Unemployed Workers? New Evidence from German Micro Data*
}

This paper provides new empirical evidence on the relationship between reservation wages of unemployed workers and macroeconomic factors - including aggregate and local unemployment rates, generosity of the unemployment compensation system and characteristics of the wage structure - as well as individual-specific determinants, including proxies for general and specific human capital, length of unemployment spell and alternative income sources. The longitudinal aspect of the dataset (the German Socio-Economic Panel) provides an interesting perspective on how reservation wages change over time and how they correlate with accepted wage offers for workers who make the transition from unemployment to employment. The findings have important policy implications as well, since they shed some light on the disincentive effects of the German tax and transfer system for the labor supply and employment decisions of unemployed workers at different points of the skill/offer wage distribution.

JEL Classification: J6, J3

Keywords: reservation wage, labor supply disincentives, offer wage distribution, unemployment and employment determinants

\author{
Eswar S. Prasad \\ Asia and Pacific Department \\ International Monetary Fund \\ 700 19th Street, N.W. \\ Washington, DC 20431 \\ USA \\ Tel.: +1 $202623-8493$ \\ Fax: +1 202 589-8493 \\ Email: eprasad@imf.org
}

\footnotetext{
* I have benefited from discussions with John Haisken-DeNew, Jennifer Hunt, Astrid Kunze, JeanMarc Robin, Axel Schimmelpfennig and numerous other colleagues and from the comments of participants at the GSOEP 2000 Conference, the World Congress of the Econometric Society, the CEPR European Summer Symposium in Labor Economics, the European Central Bank's Labor Market Workshop and seminars in the European and Research Departments of the IMF. I am grateful to John Haisken-DeNew and Jurgen Schupp for assistance with the data. The views expressed in this paper are those of the author and do not necessarily reflect those of the IMF.
} 


\section{Introduction}

The reservation wage is an important concept for modeling certain key aspects of labor market dynamics. In particular, the theory of optimal job search typically implies the reservation wage property in the context of structural models of job search behavior. The reservation wage is also a concept that has relevance for modeling labor supply decisions, through its influence on transitions from nonemployment to employment. Understanding the factors, both microeconomic and macroeconomic, that influence the reservation wage is, therefore, of considerable importance from both analytical and policy perspectives.

In this paper, I provide an empirical analysis of the determinants of reservation wages using individual data from the German Socio Economic Panel (GSOEP). One of the questions included in the survey explicitly asks unemployed workers what wage rate would have to be offered in order for them to consider accepting a job, i.e., their reservation wage. In addition, the GSOEP is particularly well suited to the analysis of reservation wages since it includes a rich set of individual- and household-specific characteristics. In this paper, I also exploit another strength of the GSOEP, which is the availability, in each survey wave, of detailed retrospective information on employment and income histories for individual workers. For the purposes of analyzing reservation wages, this dataset is unique in that the longitudinal aspect enables direct comparisons of reservation wages with accepted wages in future periods and can also be used to examine changes in reservation wages over time. Earlier studies of reservation wages have typically had access to only one year's worth of data on reservation wages and, to the best of my knowledge, none have had access to both past wages and future accepted wages. Thus, unlike in earlier studies, this dataset permits a direct validation of the quality of the reservation wage data, a perennial concern that can not be addressed in most other datasets that contain reservation wage data.

Previous studies of reservation wages have been based on far less comprehensive information and have generally been limited to either making indirect inferences about reservation wages (e.g., Kiefer and Neumann, 1979; Blau, 1991) or using one or two years of data, sometimes with little retrospective information about employment or income histories 
(e.g., Franz, 1982; Lancaster and Chesher, 1983; Feldstein and Poterba, 1984; Jones, 1988, 1989; Hui, 1991).

The results in this paper are of analytical interest from a number of different perspectives. Understanding the determinants of reservation wages could shed light on various aspects of labor supply and job search behavior. Theoretical models of job search also typically have strong implications regarding the relationships between reservation wages and variables such as unemployment duration. Rather than test a particular structural model, however, in this paper my strategy is to estimate reduced-form equations in order to model the determinants of reservation wages, thereby providing indirect evidence on the empirical relevance of some of these theoretical models.

The analysis presented here is of considerable policy relevance as well. In the final part of the paper, I develop an empirical procedure that enables me to use the reservation wage data to shed some light on one of the main problems facing the West German labor market - the high rate of nonemployment among low-skilled workers. In particular, a comparison of the ratio of reservation wages to market offer wages at different points of the skill distribution suggests that there exist labor supply rigidities at the low end of the skill/wage distribution. In tandem with the results of an earlier paper (Prasad, 2000), I argue that the results indicate the need for comprehensive reforms to influence both labor demand and labor supply at the low end of the skill/wage distribution in order to solve the German unemployment problem. ${ }^{1}$

\section{Theoretical Framework}

In this section, I discuss the main elements of a simple theoretical framework that is relevant for the analysis of reservation wages. Standard (and somewhat stripped down) models of job search imply that the reservation wage is a function of the offer wage distribution, the arrival rate of job offers and search costs. Search costs could, of course, be

\footnotetext{
${ }^{1}$ Freeman and Schettkat (2000), by contrast, argue that the German unemployment problem is mainly a consequence of deficient aggregate demand.
} 
determined by individual-specific factors as well as institutional factors such as the features of the unemployment compensation (UC) system. ${ }^{2}$ The availability of detailed individualand household-specific information is, thus, crucial for analyzing the determinants of reservation wages. For instance, conditional on other characteristics, an agent with alternative sources of income and/or other employed family members would tend to have lower search costs. Furthermore, agents in households with higher levels of wealth might have better access to financial instruments to insure against labor income risk and, would, therefore tend to have higher reservation wages.

Macroeconomic determinants are likely to play a role as well in determining reservation wages. Aggregate demand conditions (and, hence, the derived demand for labor) could influence both the overall offer wage distribution and the arrival rate of job offers and, therefore, affect reservation wages. The general equilibrium effects are, however, unclear. For instance, a higher local unemployment rate could drive down reservation wages as job offers become scarcer. On the other hand, since it presumably implies a lower real wage (if real wages are procyclical) and a lower probability of employment for workers with low levels of human capital, a drop in job search intensity could result from such workers' intertemporal optimization decisions. Workers at the margin might then drop out of job search altogether, driving up the observed distribution of reservation wages among workers engaged in active job search.

Another potential determinant of the reservation wage is unemployment duration. As discussed in more detail below, one would expect the reservation wage to decline over time on account of wealth effects and human capital depreciation. However, a problem that complicates estimation with the unemployment duration variable is that the reservation wage

\footnotetext{
${ }^{2}$ The UC system in Germany has two components. The first (Arbeitslosengeld) has the characteristics of a traditional unemployment insurance system, with a well-defined termination period and a replacement rate determined by earnings on the last job. The second component (Arbeitslosenhilfe), that follows after unemployment insurance benefits have expired, is unemployment assistance. This component involves a lower replacement rate, is means-tested and is of longer duration. For the purposes of the analysis in this paper, I do not draw a distinction between these components unless explicitly stated otherwise.
} 
and the duration of unemployment could be endogenously determined. Optimal search theory, under the assumption of a stationary reservation wage, predicts a positive correlation between these variables. That is, workers with higher reservation wages tend to have longer unemployment spells. To test this prediction, and to obviate the problem of endogeneity, I use a reduced-form instrumental variables estimation approach suggested by Jones (1988) to study the relationship between reservation wages and unemployment duration.

\section{Data}

This section contains a brief description of the data used in the empirical analysis. The dataset is the public use version of the German Socio-Economic Panel (GSOEP). I restrict my analysis to residents of West Germany between the ages of 17 and 55 who, at the time of the survey, were non-employed and reported that they were looking for a full-time job. ${ }^{3}$ The distinction between non-employment and unemployment is, of course, an important one and will be considered carefully in the analysis below.

The survey question that is intended to elicit the reservation wage is: "How much would the net pay have to be for you to consider accepting a job that was offered to you now?" The possible responses are a figure for "DM per month" or "Don't know, it depends." Note that the reservation wage concept here is net monthly earnings. ${ }^{4}$ Although my dataset includes data from the 1984-97 survey waves, the reservation wage question was included in the survey only in the years 1987-89, 1992-94 and 1996-97. Observations with left-censored

\footnotetext{
${ }^{3}$ For workers older than 55 , the reservation wage may be determined by strategic considerations about the timing of retirement and exit from the labor force that are difficult to capture in the reducedform framework used in this paper. For recent entrants into the labor market, reported reservation wages might also be less reliable, especially for first-time job applicants who may have very limited knowledge about the offer wage distribution. Below, I examine the sensitivity of the results in this paper to the exclusion of younger workers.

${ }^{4}$ An important issue here is whether, as suggested by this question, job offers stipulate both the hourly wage and a contracted number of hours per month. An alternative possibility is that employers offer an hourly wage and workers then decide how much labor, in terms of hours per week or month, they want to supply at that wage rate. It seems more plausible, especially in the German context, that job offers take the form of a combined package of wages and hours that determines total monthly earnings.
} 
unemployment spells were excluded from the analysis. It should also be noted that the unemployment duration variable reflects an ongoing rather than completed spell of unemployment as of the date of the interview. All nominal variables are deflated by the CPI (1992Q4=100) for West Germany.

Summary statistics for the main variables used in the analysis are shown in Table 1. The sample has a total of 2,372 observations, of which about 60 percent are men. Note that the sample tends to have a higher proportion of younger workers, in the 17-25 and 26-35 age ranges. Net household income is adjusted by a simple equivalence scale, where each adult gets a weight of 1 and each kid under 17 gets a weight of 0.5 . Although it was possible to construct a dummy variable to capture receipt of unemployment compensation, data on the actual level of benefits was available for only about one-third of the sample.

$$
<\text { Table } 1>
$$

A potential concern is the high survey non-response rate for the reservation wage question, which could indicate that respondents have trouble understanding or interpreting this question. For instance, the non-response rate on this question among those registered as unemployed was about 25 percent. This could influence the analysis in this paper if there was a systematic pattern in the non-response rates, i.e., if non-response was correlated with any of the individual-specific characteristics. To examine this, I took the sample of unemployed workers and generated a dummy variable for non-response to the reservation wage question. I then estimated simple probit regressions (separately for men and women) of this dummy on a vector of individual-specific characteristics. The regressions had very low explanatory power (pseudo Rsquareds of about 0.01) and none of the estimated coefficients were statistically significant at conventional levels of significance. Thus, I conclude that, although the high rate of non-response to the reservation wage question is a potential concern, there is at least no obvious relationship between observed characteristics and the pattern of nonresponse. $^{5}$

\footnotetext{
${ }^{5}$ Needless to say, there could still be a correlation between unobserved individual-specific characteristics and the non-response pattern. It is worth noting that the non-response rate here is
} 
One interesting issue is whether the reported reservation wage data bear any relationship to actual economic behavior. For instance, are accepted wage offers correlated with stated reservation wages in a reasonable manner? A unique feature of the GSOEP is that, unlike previous data sets that have been used to analyze reservation wages, the panel aspect of this dataset provides a means for answering this question. ${ }^{6}$ For workers who report earnings on a full-time job in the year after a reservation wage observation, I compute the differential between accepted (time $t+1$ ) and reservation wages (time $t$ ) (both variables are deflated by the CPI). The top panel of Figure 1 plots this differential as a percent of the time $t$ reservation wage. Although the distribution of this variable has a fairly large variance, it is comforting that a majority of the observations are clustered around zero. Observations that have a positive differential--to the right of the zero line--indicate accepted wage offers that are greater than stated reservation wages. As for the observations in the left tail of the distribution, a negative differential can be rationalized on the grounds of a declining reservation wage over time for a given individual.

\section{$<$ Figure $1>$}

To examine whether reservation wages change over time, I analyze those individuals for whom the dataset contains two consecutive observations on the reservation wage. ${ }^{7}$ This change, expressed as a percent of the first reservation wage observation, is shown in the bottom panel of Figure 1. Whether reservation wages would be expected to increase or decrease over time is, of course, far from obvious. On the one hand, wealth effects and the

substantially lower than that reported in most previous studies that have used survey data on reservation wages.

${ }^{6}$ Lancaster and Chesher (1983) and Gorter and Gorter (1993) test the predictions of stationary search models using datasets that contain information for unemployed workers on the reservation wage as well as the conditional expected wage in the next employment. The dataset used by Jones (1988) also has both of those questions but he finds that, in that dataset, the responses to the two questions are not in general mutually consistent. The availability of data on actual accepted wage offers obviates many of the problems associated with the interpretation of the expected wage variable.

${ }^{7}$ If reservation wage data are available for an individual in 3 consecutive years, this results in 2 observations for the purposes of this exercise. 
cost of depreciating human capital should drive down the reservation wage over time. On the other hand, the reservation wage could actually increase over time simply as a result of increases in overall wage (offer) levels. Furthermore, increasing knowledge over time about the true offer wage distribution could result in changes in the reservation wage. Nevertheless, one would not a priori expect to see substantial changes in reservation wages from year to year for a given individual. Indeed, although there are a few observations with large increases or decreases, most of the mass of the distribution is around zero. But note that this plot does not appear to provide strong evidence in favor of the hypothesis of stationary reservation wages; as discussed below, this has important implications for the analysis that follows. ${ }^{8}$

Overall, I interpret the results in this section as indicating that the reservation wage data in the GSOEP are reliable and have the potential to provide a reasonable means of testing the determinants of reservation wages and, by extension, to shed light on certain aspects of labor supply among workers in the West German labor market

\section{Main Results}

I first examine the determinants of reservation wages using a set of reduced-form specifications that relate each individual's reservation wage to a vector of individual-specific and macroeconomic characteristics. For this part of the analysis, the data are treated as a repeated set of cross-sections. ${ }^{9}$ OLS estimates are presented in Table 2. The excluded education dummy is General Schooling. Rather than restrict the age effects to take a

\footnotetext{
${ }^{8}$ I regressed the change in the $(\log )$ reservation wage on a variety of individual-specific characteristics, duration of unemployment spell, and total and regional unemployment rates but could not detect any systematic relationships between any of these variables and changes in the reservation wage. Kiefer and Neumann (1979) find (indirect) evidence that reservation wages decline significantly with duration.

${ }^{9}$ Unfortunately, the fact that there are breaks in the availability of the reservation wage data makes it difficult to exploit fully the panel aspect of the dataset to control for unobserved individual-specific heterogeneity. Furthermore, on account of sample attrition, attempts to construct a longitudinal dataset implied a substantially smaller number of observations than in the cross-sectional approach adopted here.
} 
quadratic form, I have explicitly created four age groups. In these regressions, the excluded age category is AGE2536.

$<$ Table $2>$

Results from the baseline specification are presented in the first column of Table 2. For workers with a university degree, reservation wages are about 15 percent higher than for workers with only general schooling, controlling for other characteristics. For workers with an apprenticeship or vocational training, however, reservation wages are statistically similar to those of workers with only general schooling. Relative to workers in the 26-35 age group, reservation wages are lower for workers in both younger and older age groups. Male workers have much higher reservation wages although, in large part, this probably just reflects the male wage premium that exists in Germany. Interestingly, marital status and the presence of kids in the household have little effect on reservation wages, although married men do have significantly higher reservation wages than married women. The presence of other employed persons in the household exerts a negative influence on reservation wages, suggesting "peer" effects within the household on employment search.

Individuals who live in households with higher net household income are more likely to be able to afford to wait and search for jobs with higher wages and would, therefore, be expected to have higher reservation wages. Indeed, variables that proxy for alternative sources of income and wealth, including total net household income and a dummy for home ownership, are positively correlated with reservation wages. One somewhat odd result is that the dummy for receipt of unemployment compensation is negatively correlated with the reservation wage. I investigate this further below.

Aggregate and regional unemployment rates (the latter expressed as a deviation from the aggregate unemployment rate) are not significantly correlated with the reservation wage. ${ }^{10}$ Entering unemployment rates in the regression implies a particular, and possibly

\footnotetext{
${ }^{10}$ The aggregate unemployment referred to here is for West Germany only. Note that, in general equilibrium, higher reservation wages and higher unemployment would tend to be positively correlated. The reduced-form specification used here can be viewed as being motivated by a partial equilibrium framework, in which an individual worker takes total and regional unemployment rates as given.
} 
restrictive, assumption about the effects of the overall macroeconomic environment on reservation wages. A simple alternative is to replace unemployment rates with time dummies. Although the estimated time effects do not have an economic interpretation, they should, in principle, soak up all the time-specific variation in reservation wages that are common to all individuals in a given time period. Column 2 of Table 2 reports the estimated specification with the time dummies (which were barely jointly significant at the 10 percent level). In this more general specification, the coefficients on the individual-specific variables remain very similar to those in column 1 . Since the time dummies do not seem to make much of a difference, I retain the use of the unemployment rates in further regressions since they have a more obvious economic interpretation.

Table 2 (column 3) also reports results restricted to the sub-sample of workers who, in the month of the interview, report that they are registered with the unemployment office and are also actively engaged in job search. This sample of workers excludes those nonemployed who may have weaker attachment to the labor market and whose reservation wages may therefore be less relevant in determining labor market outcomes. The reservation wage is presumably a more meaningful concept for those actively engaged in job search.

Many of the results are stronger for this sub-sample. In particular, reservation wages monotonically increase by education level, although age effects are now less significant for older labor force participants, relative to those in the 26-35 age group. One important difference relative to the previous results is that the coefficient on the dummy for receipt of unemployment compensation now turns significantly positive. This result appears more reasonable than those in the first two columns since one would expect UC and other alternative income sources to increase reservation wages.

In the last column of Table 2, I present results for those workers for whom data on the level of unemployment compensation benefits as well as information on earnings in the last job are available. The results on the other coefficients are generally similar to those in column 3. Both the past wage and the level of unemployment compensation clearly exert a strong positive effect on reservation wages. However, it should be noted that the implied 
elasticity of the reservation wage to unemployment compensation, although statistically significant, is not very large in economic terms. ${ }^{11}$

Table 3 shows results from the sample used for the fourth regression in Table 2, but with the results now broken down by gender. There are some notable differences between men and women in terms of the determinants of reservation wages. The presence of kids raises the reservation wage of men but has no effect on that of women. For men, the presence of other employed persons in the household reduces reservation wages by almost 7 percentperhaps a strong peer (or "macho") effect for German men who don't want to sit idly at home while others in their household are employed and are therefore willing to accept lower wages in order to find a job!

$<$ Table $3>$

For both men and women, the levels of UC benefits and wages on the last job are positively associated with reservation wages. However, one key difference is that the elasticity of reservation wages with respect to unemployment benefits is more than twice as large for women (0.161) than it is for men (0.069). While the statistical significance of these parameter estimates clearly indicates the disincentive effects of the UC system in terms of engendering higher reservation wages, it should again be emphasized that these estimates suggest that the quantitative impact of UC benefits on reservation wages is not very large, at least in these regression results.

\section{IV.1 Unemployment Duration and the Reservation Wage}

As discussed earlier, the duration of unemployment spell is likely to be correlated with the reservation wage, although different theories have different predictions about the sign of this relationship. Hazard models are generally preferable to linear regression models when analyzing unemployment duration. However, one problem in this context is that the

\footnotetext{
${ }^{11}$ It would be interesting to analyze in more detail how reservation wages are correlated with past earnings (see, e.g., Kaspar, 1967). In future work, I intend to examine the sensitivity of these results to the industry and other characteristics related to each worker's last employment preceding the current spell of unemployment.
} 
unemployment spell duration is measured as of the interview date and, by construction, there are no exits into employment in the period when the reservation wage is observed. Hence, I first estimate reduced-form OLS regressions for unemployment duration with the reservation wage as a dependent variable. ${ }^{12}$

The OLS estimates are presented in the first two columns of Table 4. The first regression includes the aggregate and regional unemployment rates as regressors while the second regression uses time dummies to capture a broader range of macroeconomic influences. In these regressions, the conditional correlation between the reservation wage and unemployment duration appears to be essentially zero. In fact, although not statistically significant, the parameter estimates are slightly negative. At an intuitive level, this might seem reasonable since, for the reasons cited earlier, one might expect the reservation wage to decline as the non-employment spell duration lengthens.

$$
<\text { Table } 4>
$$

As noted by Jones (1988), however, the reservation wage and unemployment duration are endogenously determined. One way to obviate this problem is to instrument for the reservation wage using variables that, except through their effects on search costs and, hence, on the reservation wage, are unlikely to have additional effects on unemployment duration. Jones (1988) uses unemployment insurance benefits as an instrument. Since the GSOEP is a richer dataset than the one used by Jones, I have a number of potential instruments available. Following some preliminary analysis for instrument relevance, I chose a small set of instruments that worked best—dummies for marital status, presence of kids and receipt of unemployment compensation.

The results from IV regressions are presented in the third column of Table 4. Remarkably, the coefficient on the log reservation wage now turns positive and significant. Again, using time dummies rather than aggregate and regional unemployment rates makes little difference to the results (column 4). The results were quite similar across alternative

\footnotetext{
${ }^{12}$ For a more detailed analysis of unemployment durations in Germany using the GSOEP dataset, see Hunt (1995).
} 
choices of instrument sets. Interestingly, the pattern of the switch of the sign in coefficients when going from OLS to IV estimates and the actual magnitudes of the coefficients on the reservation wage variable are quite similar to those found by Jones (1988), who uses a oneyear cross-sectional sample of data from the United Kingdom.

However, it should be noted that the positive correlation found here is predicted by optimal search theory under the assumption of a stationary reservation wage. The evidence in the previous section suggested that this assumption is not necessarily borne out in the data. Hence, the interpretation of the positive correlation between reservation wages and unemployment duration as being consistent with optimal search theory requires some caution and deserves further scrutiny in future work.

\section{The Relationship between Skill Levels and Reservation Wages}

In this section, I examine further the relationship between imputed skill levels and reservation wages. This analysis can be interpreted as providing some indirect evidence on labor supply, based on reservation wage data, at different points of the skill/wage distribution. This is of particular relevance for shedding light on potential determinants of rigidities in labor supply at the low end of the skill/wage distribution that could have implications for understanding the German unemployment problem.

The approach I adopt can be broken down into the following steps: (i) estimate annual selection-corrected Mincerian wage equations for full-time employed workers; (ii) based on those estimates, generate a predicted offer wage for each unemployed worker conditional on observed characteristics; and (iii) construct the reservation wage ratio - which is the ratio of reservation to (predicted) offer wages--for each worker who reports a reservation wage.

Net monthly earnings, deflated by the CPI for West Germany, are used as the dependent variable in the regression for the first step. Wage regressions were estimated separately for each year for which reservation wage data are available. The regressors included education dummies, experience and its square, dummies for citizenship and gender, and a full set of interactions of these two dummies with the other variables. Since the observed wage distribution could be a biased measure of the offer wage distribution--an issue 
of particular importance for this analysis--an expanded sample including nonemployed workers was used to estimate and correct for selectivity bias using Heckman's (1979) twostep procedure. Instruments used for the selection correction were dummies for marital status and the presence of kids. Other instruments (e.g., home ownership) seemed to add little to this limited set.

The coefficients in the selection-corrected wage regressions appeared quite stable over time, consistent with other evidence that returns to observed skill attributes have been remarkably stable in West Germany over the last decade and a half (e.g., Prasad, 2000). To conserve space, the results of these wage regressions are not reported here but are available from the author upon request. In the discussion below, it should be kept in mind that, in these annual wage regressions, observed worker characteristics explain only about 30-40 percent of the cross-sectional variation in wages. ${ }^{13}$

In Figure 2, I plot the reservation wage ratio against the offer wage, which may be considered a comprehensive measure of skill level. The top panel pools observations across all years. The vertical line shows the median real wage across all years for which the reservation wage data are available. As noted earlier, all wage variables including imputed ones correspond to net measures of real monthly earnings.

$<$ Figure $2>$

The interesting observation from this figure is that appears to be a negative relationship between the reservation-offer wage ratio and skill level. For most highly skilled workers in the sample--those whose offer wages lie to the right of the median--the reservation wage ratio is below one. For these workers, the value of employment is apparently high enough that they are willing to accept employment even slightly below their market offer wage. This could be because of the much greater value of skilled workers' human capital investments and the associated higher absolute amount of depreciation of that capital as unemployment duration increases. By contrast, for a large fraction of low-skill

\footnotetext{
${ }^{13}$ This fraction is quite similar across data sets for many industrial countries and appears to be almost a law of nature.
} 
workers, reservation wages appear significantly higher than market offer wages, and this relationship is stronger at lower skill levels.

The lower panels of Figure 2 plot reservation wage ratios against offer wages for men and women separately. ${ }^{14}$ The positive male-female wage differential, conditional on observed worker characteristics, is apparent as one can infer from these panels that (for the sample of unemployed workers) the distributions of both offer and reservation wages for women are to the left of the corresponding distributions for men. But the negative relationship between the reservation wage ratio and the composite measure of skills proxied by the offer wage holds for both men and women. I also redid the plots separately for each year and found that the negative relationship between the reservation wage ratio and the offer wage was present in every year taken individually. Limiting the sample to workers engaged in active job search at the time of the survey also revealed a similar result.

In interpreting this evidence, an important underlying assumption concerns the unobserved worker characteristics that could affect the conditional offer wage distribution facing a worker. The comparison of reservation and offer wages is based on the assumption that the effect of unobserved characteristics on reservation wages is uncorrelated with residuals from the estimated wage equations; these residuals could partly be driven by some of those same unobserved characteristics. Even if this assumption were not true, however, there is no a priori reason why the magnitude of this correlation should be systematically related to observed skill level. Hence, while the levels of the reservation wage ratios must be interpreted with caution, systematic relationships between reservation wage ratios and observed worker characteristics can not simply be ascribed to this correlation.

I now turn to a discussion of the implications of these findings for interpreting labor market outcomes and for labor market policies in (West) Germany to address the unemployment problem.

\footnotetext{
${ }^{14}$ As noted earlier, these results are based on estimates of selection-corrected wage equations for the sample including both men and women. Re-estimating the wage equations separately for men and women and recomputing the reservation wage ratios based on those estimates made little qualitative difference to the results.
} 


\section{V.1 Implications for Labor Market Policies}

In an earlier paper (Prasad, 2000), I have argued that the inability of the German wage structure to adjust to an increase in the relative demand for skilled labor has led to substitution of capital and skilled labor for unskilled labor and, consequently, rising nonemployment rates for unskilled workers in Germany. A possible concern with that analysis is that the offer wage distribution could in fact be truncated from below on account of high reservation wages. Thus, the apparent rigidity of the wage structure might be reflective not of institutional constraints imposed by the wage bargaining structure but rigidities in labor supply caused, perhaps, by other factors such as the UC system.

The cluster of reservation wage ratios for labor force participants below the median wage and even close to the left tail of the skill distribution suggests that this issue is not of great empirical relevance. There appear to be enough low-skill workers willing to work at wages below their market offer wages if jobs were available. Thus, labor demand is apparently one of the problems inhibiting better employment outcomes for low-skill workers. Nevertheless, the large number of observations with reservation wage ratios above unity suggests that labor supply is also a problem at the low end of the skill distribution and that measures to influence labor demand alone would have a relatively small effect since a large number of unskilled workers are not willing to work at the going wage.

Regression results (not reported here) confirmed the existence of a strong negative relationship between the reservation-offer wage ratio and education level. ${ }^{15}$ This differential initially declines with age but then turns around at about 47 years of age. The differential is positively related to household net income and, more importantly, to the availability of unemployment compensation. This latter result suggests that the system of unemployment compensation appears to play a role in driving up the reservation wages of many low-skill workers and in limiting their incentives to accept job offers at their respective conditional

\footnotetext{
${ }^{15}$ The regression results reported in this section were based on OLS specifications (for the sample of unemployed workers who report a reservation wage) with the reservation-offer wage ratio as the dependent variable and a set of regressors that included education dummies, age and its square, real household net income, year dummies and dummies for gender, citizenship and receipt of unemployment compensation.
} 
offer wages. Of course, the disincentive effects of the UC system could be compounded by other aspects of the social benefits system as well as the tax system. This is an interesting topic that is left for future research. ${ }^{16}$

\section{Conclusions}

This paper has used a unique and rich dataset, the German Socio-Economic Panel, to provide a detailed empirical analysis of the determinants of reservation wages among unemployed workers in West Germany. This dataset is unique in that the (limited) longitudinal aspect enables direct comparisons of reservation wages with accepted wages in future periods and can also be used to examine changes in reservation wages over time. Earlier studies of reservation wages have typically had access to only one year's worth of data on reservation wages and none have had access to both past and future accepted wages. Thus, unlike in earlier studies, this dataset permits a direct validation of the quality of the reservation wage data, a perennial concern that can not be addressed in most other datasets that contain reservation wage data.

In the sample of West German unemployed workers analyzed here, reservation wage levels are found to be positively correlated with observed attributes of general human capital (education level), are generally higher for men, and appear to be significantly influenced by the availability of unemployment compensation. The paper also included an analysis of the reservation wage ratio - defined as the ratio of the stated reservation wage to the market offer wage, the latter variable being defined as the predicted wage from estimated wage equations that account for sample selectivity effects. The reservation wage ratio was found to be negatively correlated with observed measures of skill level.

An interesting, although tentative, implication of these results is that there appear to be significant labor supply rigidities at the low end of the German skill/wage distribution, attributable in part to the generous UC system (and perhaps also to other factors such as high

\footnotetext{
${ }^{16}$ Jaeger (1999) has also argued that the high effective marginal tax rates faced by workers at low income levels deter the acceptance of job offers in low earnings ranges.
} 
effective marginal tax rates). A key policy conclusion that emerges from this and my previous work is that comprehensive reforms that influence both labor demand (by allowing for more flexibility in the dispersion of wages) and labor supply (by changing the disincentives for seeking employment) at the low end of the skill/wage distribution could be crucial for solving the structural problem of high nonemployment rates for low-skill workers in West Germany. 


\section{References}

Blau, David M. (1991) "Search for Nonwage Job Characteristics: A Test of the Reservation Wage Hypothesis," Journal of Labor Economics, Vol. 9, pp. 186-205.

Feldstein, Martin, and James Poterba (1984) "Unemployment Insurance and Reservation Wages," Journal of Public Economics, Vol. 23, pp. 141-67.

Franz, Wolfgang (1982) "The Reservation Wage of Unemployed Persons in the Federal Republic of Germany: Theory and Empirical Tests," Zeitschrift für Wirtschafts-und Sozialwissenschaften, Vol. 102, pp. 29-51.

Freeman, Richard B., and Ronald Schettkat (2000) "The Role of Wage and Skill Differences in U.S.-German Employment Differences,” NBER Working Paper No. 7474.

Gorter, Dirk and Cees Gorter (1993) "The Relation Between Unemployment Benefits, the Reservation Wage and Search Duration," Oxford Bulletin of Economics and Statistics, Vol. 55, pp. 199-214.

Hui, Weng-Tat (1991) "Reservation Wage Analysis of Unemployed Youths in Australia," Applied Economics, Vol. 23, pp. 1341-50.

Hunt, Jennifer (1995) “The Effect of Unemployment Compensation on Unemployment Duration in Germany," Journal of Labor Economics, Vol. 13:1, pp. 88-120.

Jaeger, Albert (1999) "Institutional Change and Economic Performance in Germany: A Fifty Year Perspective," Manuscript, IMF.

Jones, Stephen R.G. (1988) "The Relationship between Unemployment Spells and Reservation Wages as a Test of Search Theory," Quarterly Journal of Economics, Vol. 103, pp. 741-65.

Jones, Stephen R.G. (1989) "Reservation Wages and the Cost of Unemployment," Economica, Vol. 56, pp. 225-46.

Kaspar, Hirschel (1967) "The Asking Price of Labor and the Duration of Unemployment," Review of Economics and Statistics, Vol. 49, pp. 165-72.

Kiefer, Nicholas M. and George R. Neumann (1979) “An Empirical Job-Search Model, with a Test of the Constant Reservation-Wage Hypothesis," Journal of Political Economy, Vol. 87:1, pp. 89-107.

Lancaster, Tony and Andrew Chesher (1983) "An Econometric Analysis of Reservation Wages," Econometrica, Vol. 51, pp. 1661-76. 
Prasad, Eswar S. (2000) "The Unbearable Stability of the German Wage Structure: Evidence and Interpretation," IMF Working Paper 00/20.

Schmidt, Christoph M. and Rainer Winkelmann (1993) "Reservation Wages, Wage Offer Distribution and Accepted Wages" in H. Bunzel, P. Jensen and N. Westergard-Nielsen (eds.) Panel Data and Labor Market Dynamics (Amsterdam: North-Holland).

Schmidt, Christoph M. (1993) "Testing the Stationary Search Model," in H. Schneewei and K.F. Zimmermann (eds.) Studies in Applied Econometrics (Heidelberg: PhysicaVerlag). 
Table 1. Summary Statistics

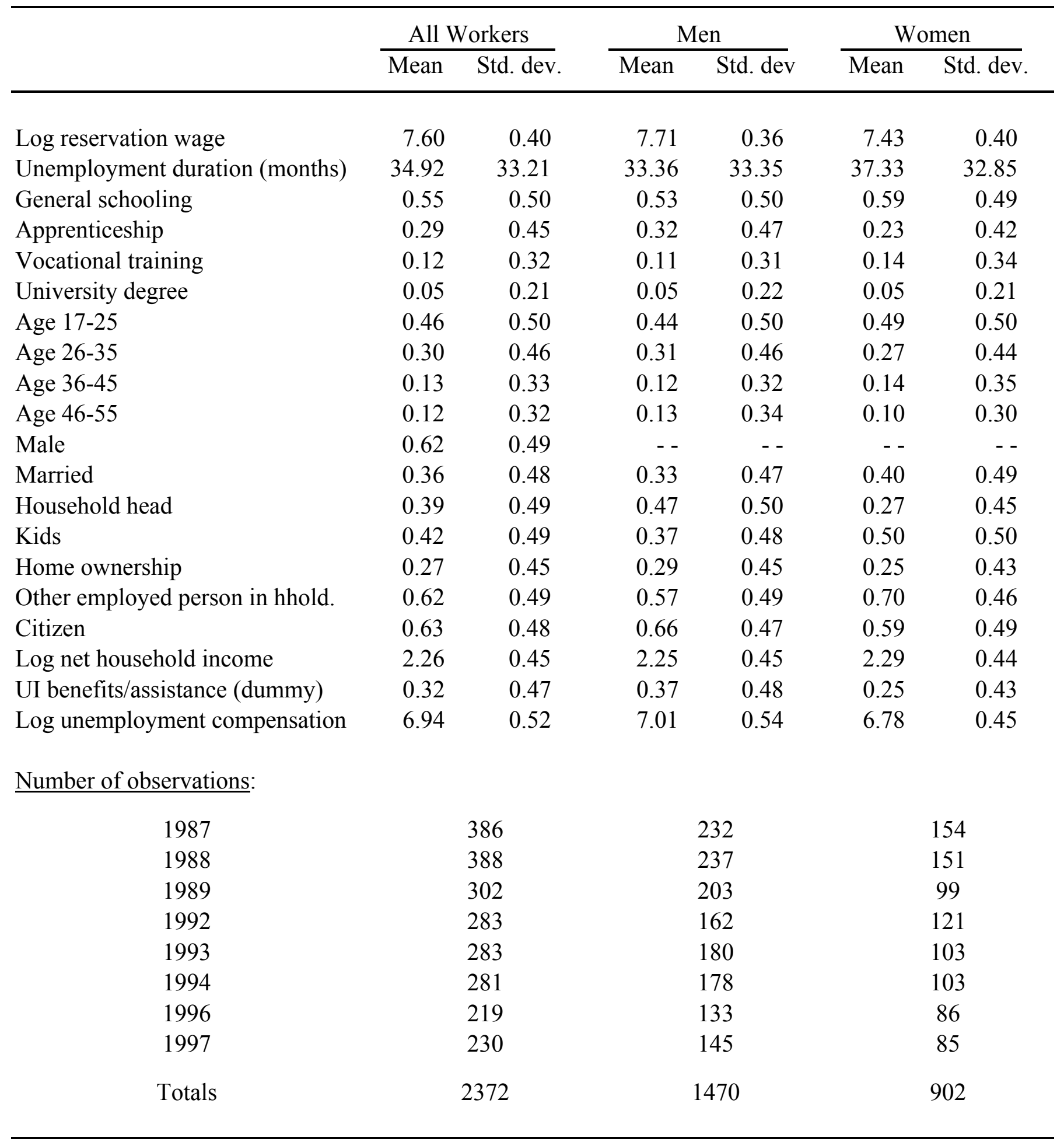

Notes: The reservation wage is defined in terms of real net monthly earnings. Net household income is adjusted by a simple equivalence scale where each adult gets a weight of 1 and each kid under 17 gets a weight of 0.5 . Data on amounts of unemployment compensation were available only for 704 observations (500 men, 204 women). All nominal variables were deflated by the CPI (1992Q4=100) for West 
Table 2. Determinants of the Reservation Wage: OLS Regressions Dependent Variable: Log Reservation Wage

\begin{tabular}{|c|c|c|c|c|c|}
\hline & (1) & (2) & (3) & (4) & \\
\hline Apprenticeship & $\begin{array}{c}0.002 \\
(0.019)\end{array}$ & $\begin{array}{l}-0.006 \\
(0.019)\end{array}$ & $\begin{array}{l}0.047 * \\
(0.021)\end{array}$ & $\begin{array}{c}0.013 \\
(0.023)\end{array}$ & \\
\hline Vocational training & $\begin{array}{c}0.025 \\
(0.021)\end{array}$ & $\begin{array}{c}0.028 \\
(0.021)\end{array}$ & $\begin{array}{l}0.074 * \\
(0.022)\end{array}$ & $\begin{array}{c}0.052 \\
(0.026)\end{array}$ & $*$ \\
\hline University degree & $\begin{array}{c}0.161 * \\
(0.039)\end{array}$ & $\begin{array}{l}0.156 * \\
(0.040)\end{array}$ & $\begin{array}{l}0.315 * \\
(0.047)\end{array}$ & $\begin{array}{c}0.254 \\
(0.051)\end{array}$ & $*$ \\
\hline Age $17-25$ & $\begin{array}{l}-0.112 * \\
(0.020)\end{array}$ & $\begin{array}{l}-0.105 * \\
(0.020)\end{array}$ & $\begin{array}{l}-0.089 * \\
(0.026)\end{array}$ & $\begin{array}{l}-0.074 \\
(0.027)\end{array}$ & $*$ \\
\hline Age $36-45$ & $\begin{array}{l}-0.097 * \\
(0.021)\end{array}$ & $\begin{array}{l}-0.083 * \\
(0.021)\end{array}$ & $\begin{array}{l}-0.017 \\
(0.023)\end{array}$ & $\begin{array}{l}-0.032 \\
(0.025)\end{array}$ & \\
\hline Age $46-55$ & $\begin{array}{l}-0.125 * \\
(0.024)\end{array}$ & $\begin{array}{l}-0.111 * \\
(0.024)\end{array}$ & $\begin{array}{l}-0.029 \\
(0.024)\end{array}$ & $\begin{array}{l}-0.013 \\
(0.027)\end{array}$ & \\
\hline Male & $\begin{array}{c}0.213 * \\
(0.025)\end{array}$ & $\begin{array}{l}0.217 * \\
(0.025)\end{array}$ & $\begin{array}{l}0.131 * \\
(0.026)\end{array}$ & $\begin{array}{l}-0.152 \\
(0.031)\end{array}$ & $*$ \\
\hline Married & $\begin{array}{l}-0.051 \\
(0.029)\end{array}$ & $\begin{array}{l}-0.045 \\
(0.029)\end{array}$ & $\begin{array}{l}-0.068 * \\
(0.034)\end{array}$ & $\begin{array}{l}-0.092 \\
(0.038)\end{array}$ & $*$ \\
\hline Male * married & $\begin{array}{c}0.201 \\
(0.035)\end{array}$ & $\begin{array}{l}0.198 * \\
(0.034)\end{array}$ & $\begin{array}{l}0.203 * \\
(0.038)\end{array}$ & $\begin{array}{c}0.128 \\
(0.040)\end{array}$ & $*$ \\
\hline Kids & $\begin{array}{l}-0.004 \\
(0.020)\end{array}$ & $\begin{array}{l}-0.002 \\
(0.020)\end{array}$ & $\begin{array}{l}0.059 * \\
(0.021)\end{array}$ & $\begin{array}{c}0.047 \\
(0.023)\end{array}$ & $*$ \\
\hline Other emp. person(s) in hhold. & $\begin{array}{l}-0.115 * \\
(0.019)\end{array}$ & $\begin{array}{l}-0.104 * \\
(0.019)\end{array}$ & $\begin{array}{l}-0.104 * \\
(0.021)\end{array}$ & $\begin{array}{l}-0.066 \\
(0.021)\end{array}$ & \\
\hline Home ownership & $\begin{array}{c}0.085 * \\
(0.022)\end{array}$ & $\begin{array}{l}0.087 * \\
(0.022)\end{array}$ & $\begin{array}{c}0.008 \\
(0.022)\end{array}$ & $\begin{array}{l}-0.008 \\
(0.026)\end{array}$ & \\
\hline Log net household income & $\begin{array}{l}0.195 * \\
(0.022)\end{array}$ & $\begin{array}{l}0.184 * \\
(0.022)\end{array}$ & $\begin{array}{l}0.096 * \\
(0.027)\end{array}$ & $\begin{array}{c}0.058 \\
(0.027)\end{array}$ & $*$ \\
\hline Citizen & $\begin{array}{l}-0.004 \\
(0.022)\end{array}$ & $\begin{array}{c}0.004 \\
(0.021)\end{array}$ & $\begin{array}{l}-0.026 \\
(0.023)\end{array}$ & $\begin{array}{l}-0.045 \\
(0.022)\end{array}$ & $*$ \\
\hline UC dummy & $\begin{array}{l}-0.082 * \\
(0.015)\end{array}$ & $\begin{array}{l}-0.095 * \\
(0.015)\end{array}$ & $\begin{array}{l}0.038 * \\
(0.018)\end{array}$ & -- & \\
\hline Log UC benefits & - - & - - & -- & $\begin{array}{c}0.094 \\
(0.021)\end{array}$ & $*$ \\
\hline Log past wage & -- & -- & -- & $\begin{array}{c}0.178 \\
(0.030)\end{array}$ & \\
\hline Unemployment rate & $\begin{array}{l}-0.006 \\
(0.006)\end{array}$ & -- & $\begin{array}{l}-0.002 \\
(0.006)\end{array}$ & $\begin{array}{l}-0.010 \\
(0.007)\end{array}$ & \\
\hline Regional unemployment rate & $\begin{array}{l}-0.003 \\
(0.004)\end{array}$ & -- & $\begin{array}{l}-0.003 \\
(0.004)\end{array}$ & $\begin{array}{c}0.003 \\
(0.004)\end{array}$ & \\
\hline Year dummies & -- & included & - - & -- & \\
\hline Adj. Rsquared & 0.227 & 0.244 & 0.333 & 0.500 & \\
\hline Nobs. & 2371 & 2371 & 1073 & 547 & \\
\hline
\end{tabular}

Notes: The first two columns include the full sample. The third column is limited to workers who are officially registered as unemployed. The fourth column is restricted to registered unemployed workers for whom data on amounts of unemployment compensation are available. The excluded education dummy in all regressions is "general schooling." The excluded age dummy is AGE2635. Robust standard errors are reported in parentheses below coefficient estimates. An asterisk indicates statistical significance at the 5 percent level. 
Table 3. Determinants of Reservation Wage, by Gender: OLS Regressions Dependent Variable: Log Reservation Wage

\begin{tabular}{|c|c|c|}
\hline & Men & Women \\
\hline Apprenticeship & $\begin{array}{l}0.022 \\
(0.027)\end{array}$ & $\begin{array}{c}0.007 \\
(0.051)\end{array}$ \\
\hline Vocational training & $\begin{array}{l}0.074 \\
(0.029)\end{array}$ & $\begin{array}{c}0.016 \\
(0.054)\end{array}$ \\
\hline University degree & $\begin{array}{l}0.213 \\
(0.073)\end{array}$ & $\begin{array}{l}0.290 \\
(0.075)\end{array}$ \\
\hline Age $17-25$ & $\begin{array}{l}-0.066 * \\
(0.032)\end{array}$ & $\begin{array}{l}-0.089 \\
(0.052)\end{array}$ \\
\hline Age $36-45$ & $\begin{array}{c}0.001 \\
(0.031)\end{array}$ & $\begin{array}{l}-0.100 * \\
(0.047)\end{array}$ \\
\hline Age $46-55$ & $\begin{array}{l}-0.007 \\
(0.032)\end{array}$ & $\begin{array}{l}-0.004 \\
(0.072)\end{array}$ \\
\hline Married & $\begin{array}{l}0.031 \\
(0.027)\end{array}$ & $\begin{array}{l}-0.074 \\
(0.053)\end{array}$ \\
\hline Kids & $\begin{array}{l}0.082 \\
(0.027)\end{array}$ & $\begin{array}{l}-0.013 \\
(0.042)\end{array}$ \\
\hline Other emp. person(s) in hhold. & $\begin{array}{l}-0.070 * \\
(0.024)\end{array}$ & $\begin{array}{l}-0.067 \\
(0.044)\end{array}$ \\
\hline Home ownership & $\begin{array}{l}-0.007 \\
(0.033)\end{array}$ & $\begin{array}{l}-0.016 \\
(0.048)\end{array}$ \\
\hline Log net household income & $\begin{array}{l}0.092 \\
(0.032)\end{array}$ & $\begin{array}{l}-0.030 \\
(0.057)\end{array}$ \\
\hline Citizen & $\begin{array}{l}-0.033 \\
(0.025)\end{array}$ & $\begin{array}{l}-0.081 \\
(0.044)\end{array}$ \\
\hline UC dummy & -- & -- \\
\hline Log UC benefits & $\begin{array}{l}0.069 * \\
(0.022)\end{array}$ & $\begin{array}{c}0.161 * \\
(0.044)\end{array}$ \\
\hline Log past wage & $\begin{array}{l}0.170 * \\
(0.036)\end{array}$ & $\begin{array}{l}0.178 * \\
(0.061)\end{array}$ \\
\hline Unemployment rate & $\begin{array}{l}-0.005 \\
(0.008)\end{array}$ & $\begin{array}{l}-0.015 \\
(0.016)\end{array}$ \\
\hline Regional unemployment rate & $\begin{array}{l}0.003 \\
(0.005)\end{array}$ & $\begin{array}{l}0.003 \\
(0.007)\end{array}$ \\
\hline Adj. Rsquared & 0.333 & 0.461 \\
\hline Nobs. & 394 & 153 \\
\hline
\end{tabular}

Notes: The regressions reported above were restricted to registered unemployed workers for whom data on amounts of unemployment compensation are available. The excluded education dummy in all regressions is "general schooling." The excluded age dummy is AGE2635. Robust standard errors are reported in parentheses below coefficient estimates. An asterisk indicates statistical significance at the 5 percent level. 
Table 4. Unemployment Duration and Reservation Wages

Dependent Variable_-Log Unemployment Duration (months)

\begin{tabular}{|c|c|c|c|c|}
\hline & OLS & OLS & IV & IV \\
\hline Log reservation wage & $\begin{array}{l}-0.083 \\
(0.117)\end{array}$ & $\begin{array}{l}-0.059 \\
(0.119)\end{array}$ & $\begin{array}{r}4.431 * \\
(1.985)\end{array}$ & $\begin{array}{l}3.359 \\
(1.484)\end{array}$ \\
\hline Apprenticeship & $\begin{array}{l}-0.408 * \\
(0.111)\end{array}$ & $\begin{array}{l}-0.398 * \\
(0.112)\end{array}$ & $\begin{array}{l}-0.776 * \\
(0.221)\end{array}$ & $\begin{array}{l}-0.645 * \\
(0.169)\end{array}$ \\
\hline Vocational training & $\begin{array}{l}-0.219 \\
(0.123)\end{array}$ & $\begin{array}{l}-0.238 \\
(0.124)\end{array}$ & $\begin{array}{l}-0.529 * \\
(0.220)\end{array}$ & $\begin{array}{l}-0.467 * \\
(0.182)\end{array}$ \\
\hline University degree & $\begin{array}{c}0.067 \\
(0.185)\end{array}$ & $\begin{array}{c}0.070 \\
(0.181)\end{array}$ & $\begin{array}{l}-0.918 \\
(0.526)\end{array}$ & $\begin{array}{l}-0.659 \\
(0.410)\end{array}$ \\
\hline Age $17-25$ & $\begin{array}{l}-0.088 \\
(0.112)\end{array}$ & $\begin{array}{l}-0.092 \\
(0.114)\end{array}$ & $\begin{array}{l}0.775 \\
(0.407)\end{array}$ & $\begin{array}{c}0.523 \\
(0.295)\end{array}$ \\
\hline Age $36-45$ & $\begin{array}{l}-0.255 \\
(0.153)\end{array}$ & $\begin{array}{l}-0.271 \\
(0.153)\end{array}$ & $\begin{array}{l}0.074 \\
(0.236)\end{array}$ & $\begin{array}{l}-0.071 \\
(0.194)\end{array}$ \\
\hline Age $46-55$ & $\begin{array}{l}-0.072 \\
(0.143)\end{array}$ & $\begin{array}{l}-0.085 \\
(0.145)\end{array}$ & $\begin{array}{l}0.369 \\
(0.289)\end{array}$ & $\begin{array}{c}0.190 \\
(0.220)\end{array}$ \\
\hline Male & $\begin{array}{l}-0.227 * \\
(0.098)\end{array}$ & $\begin{array}{l}-0.226 * \\
(0.098)\end{array}$ & $\begin{array}{l}-1.373 * \\
(0.515)\end{array}$ & $\begin{array}{l}-1.092 * \\
(0.388)\end{array}$ \\
\hline Citizen & $\begin{array}{c}0.000 \\
(0.098)\end{array}$ & $\begin{array}{l}0.013 \\
0.098)\end{array}$ & $\begin{array}{l}-0.114 \\
(0.156)\end{array}$ & $\begin{array}{l}-0.111 \\
(0.137)\end{array}$ \\
\hline Unemployment rate & $\begin{array}{l}-0.020 \\
(0.035)\end{array}$ & - & $\begin{array}{c}0.041 \\
(0.058)\end{array}$ & - \\
\hline Regional unemployment rate & $\begin{array}{l}0.047 * \\
(0.019)\end{array}$ & - & $\begin{array}{c}0.053 \\
(0.028)\end{array}$ & - \\
\hline Year dummies & - & included & - - & included \\
\hline $\begin{array}{l}\text { Adj. Rsquared } \\
\text { Nobs. }\end{array}$ & $\begin{array}{l}0.041 \\
1151\end{array}$ & $\begin{array}{l}0.041 \\
1151\end{array}$ & $\begin{array}{l}-- \\
1151\end{array}$ & -- \\
\hline
\end{tabular}

Notes: In the IV regressions, the (log) reservation wage is instrumented using dummies for receipt of unemployment compensation, marital status, presence of kids, and home ownership. Robust standard errors are reported in parentheses. An asterisk indicates statistical significance at the 5 percent level. 


\section{Figure 1. Validating the Reservation Wage}
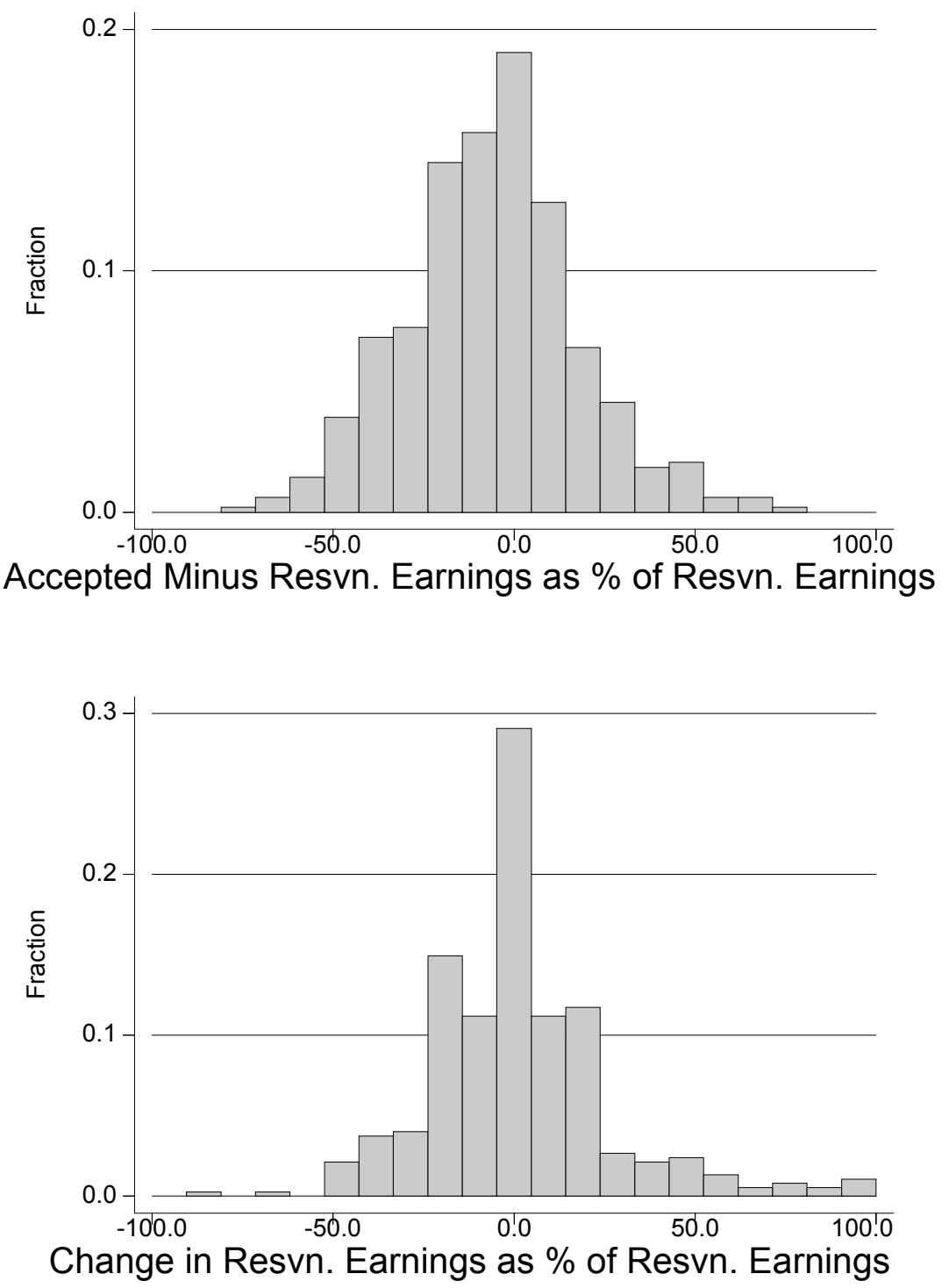


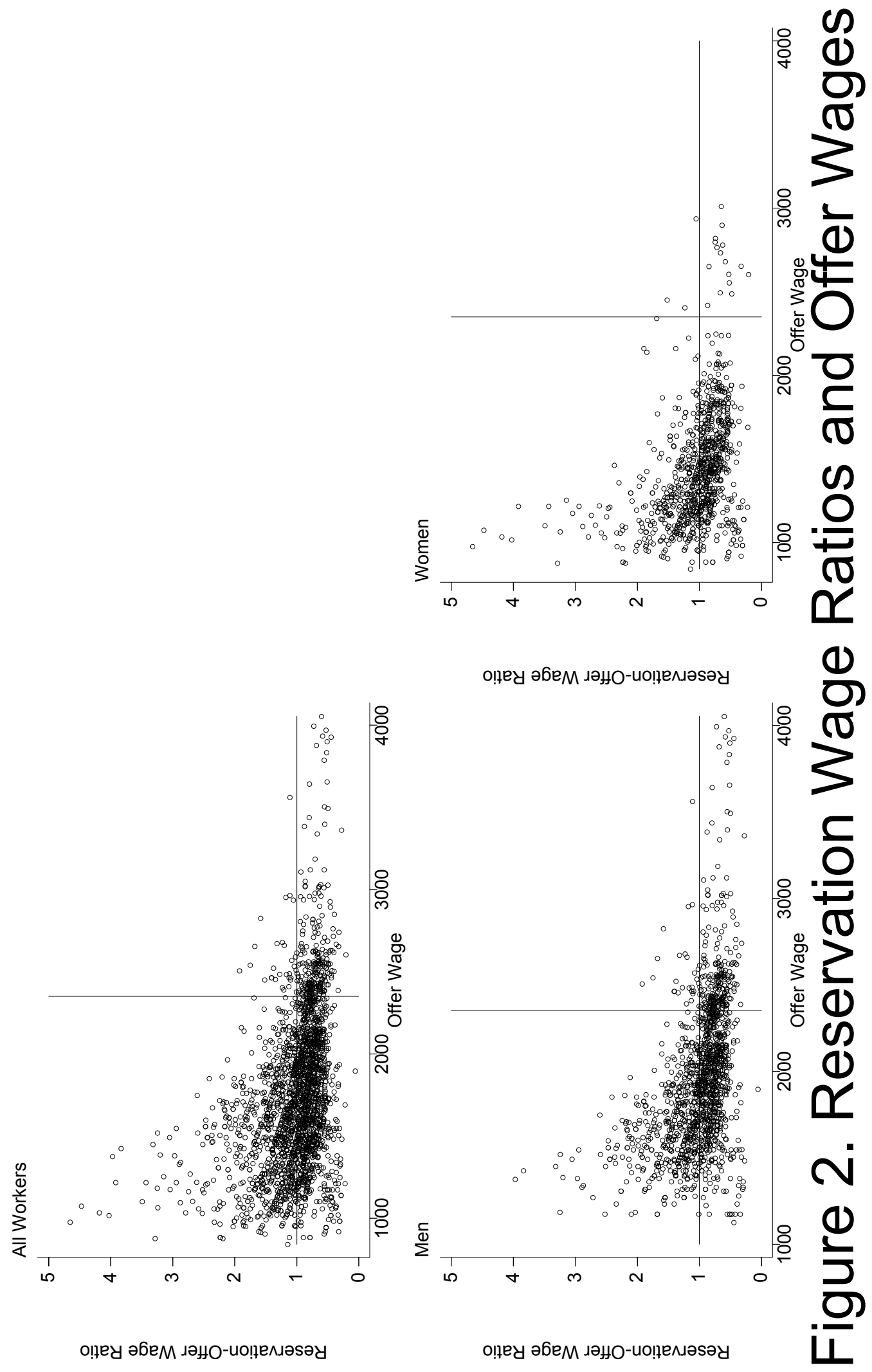




\section{IZA Discussion Papers}

\begin{tabular}{|c|c|c|c|c|}
\hline No. & Author(s) & Title & Area & Date \\
\hline 679 & $\begin{array}{l}\text { A. Kölling } \\
\text { C. Schnabel } \\
\text { J. Wagner }\end{array}$ & $\begin{array}{l}\text { Establishment Age and Wages: Evidence from } \\
\text { German Linked Employer-Employee Data }\end{array}$ & 1 & $12 / 02$ \\
\hline 680 & $\begin{array}{l}\text { M. Hagedorn } \\
\text { A. Kaul }\end{array}$ & $\begin{array}{l}\text { Langzeitarbeitslosigkeit in Deutschland: Fakten, } \\
\text { Ursachen und Bekämpfung }\end{array}$ & 7 & $12 / 02$ \\
\hline 681 & $\begin{array}{l}\text { M. Hagedorn } \\
\text { A. Kaul } \\
\text { T. Mennel }\end{array}$ & $\begin{array}{l}\text { An Adverse Selection Model of Optimal } \\
\text { Unemployment Insurance }\end{array}$ & 7 & $12 / 02$ \\
\hline 682 & B. Cockx & $\begin{array}{l}\text { Vocational Training of Unemployed Workers in } \\
\text { Belgium }\end{array}$ & 2 & $01 / 03$ \\
\hline 683 & E. Strobl & $\begin{array}{l}\text { Is Education Used as a Signaling Device for } \\
\text { Productivity in Developing Countries? Evidence } \\
\text { from Ghana }\end{array}$ & 4 & $01 / 03$ \\
\hline 684 & P. A. Puhani & $\begin{array}{l}\text { The Rise and Fall of Swiss Unemployment: } \\
\text { Relative Demand Shocks, Wage Rigidities, and } \\
\text { Temporary Immigrants }\end{array}$ & 2 & $01 / 03$ \\
\hline 685 & $\begin{array}{l}\text { L. Borghans } \\
\text { B. ter Weel }\end{array}$ & $\begin{array}{l}\text { Do We Need Computer Skills to Use a } \\
\text { Computer? Evidence from Britain }\end{array}$ & 2 & $01 / 03$ \\
\hline 686 & $\begin{array}{l}\text { A. S. Kalwij } \\
\text { R. Alessie }\end{array}$ & $\begin{array}{l}\text { Permanent and Transitory Wage Inequality of } \\
\text { British Men, 1975-2001: Year, Age and Cohort } \\
\text { Effects }\end{array}$ & 2 & $01 / 03$ \\
\hline 687 & $\begin{array}{l}\text { I. Haouas } \\
\text { M. Yagoubi } \\
\text { A. Heshmati }\end{array}$ & $\begin{array}{l}\text { Labour-Use Efficiency in Tunisian Manufacturing } \\
\text { Industries }\end{array}$ & 4 & $01 / 03$ \\
\hline 688 & $\begin{array}{l}\text { I. Haouas } \\
\text { M. Yagoubi } \\
\text { A. Heshmati }\end{array}$ & $\begin{array}{l}\text { The Impacts of Trade Liberalization on } \\
\text { Employment and Wages in Tunisian Industries }\end{array}$ & 4 & $01 / 03$ \\
\hline 689 & $\begin{array}{l}\text { I. Haouas } \\
\text { A. Heshmati }\end{array}$ & $\begin{array}{l}\text { The Effects of Union Wage-Settings on Firms' } \\
\text { Production Factor Decisions }\end{array}$ & 5 & $01 / 03$ \\
\hline 690 & M. Hagedorn & Contracting with Private Information & 1 & $01 / 03$ \\
\hline 691 & $\begin{array}{l}\text { B. Petrongolo } \\
\text { C. Pissarides }\end{array}$ & Scale Effects in Markets with Search & 3 & $01 / 03$ \\
\hline 692 & $\begin{array}{l}\text { T. E. Smith } \\
\text { Y. Zenou }\end{array}$ & $\begin{array}{l}\text { Spatial Mismatch, Search Effort and Urban } \\
\text { Spatial Structure }\end{array}$ & 3 & $01 / 03$ \\
\hline 693 & $\begin{array}{l}\text { L. Gobillon } \\
\text { H. Selod } \\
\text { Y. Zenou }\end{array}$ & $\begin{array}{l}\text { Spatial Mismatch: From the Hypothesis to the } \\
\text { Theories }\end{array}$ & 3 & $01 / 03$ \\
\hline 694 & E. S. Prasad & $\begin{array}{l}\text { What Determines the Reservation Wages of } \\
\text { Unemployed Workers? New Evidence from } \\
\text { German Micro Data }\end{array}$ & 3 & $01 / 03$ \\
\hline
\end{tabular}

An updated list of IZA Discussion Papers is available on the center's homepage www.iza.org. 